\title{
ARTICLE
}

\section{Annual, seasonal and daily variation in the abundance of the South American sea lion Otaria flavescens in two breeding colonies in northern Chile}

\author{
Variaciones anuales, estacionales y diarias en la abundancia del lobo marino común \\ Otaria flavescens en dos colonias reproductivas del norte de Chile

\section{Maritza Sepúlveda ${ }^{1,2}$, Macarena Santos ${ }^{1,2}$, Rodrigo Veas ${ }^{3}$, Lily Muñoz ${ }^{1}$, Danai Olea ${ }^{1}$, Rodrigo Moraga $^{2}$ and Walter Sielfeld ${ }^{4}$}

\author{
${ }^{1}$ Centro de Investigación y Gestión de los Recursos Naturales (CIGREN), Instituto de Biología, Facultad de Ciencias, \\ Universidad de Valparaíso, Gran Bretaña 1111, Playa Ancha, Valparaíso, Chile. maritza.sepulveda@uv.cl \\ ${ }^{2}$ Centro de Investigación Eutropia, Ahumada 131, Oficina 912, Santiago, Chile \\ ${ }^{3}$ Programa de Investigación Marina de Excelencia (PIMEX), Facultad de Ciencias Naturales y Oceanográficas, Casilla 160- \\ C, Universidad de Concepción, Chile \\ ${ }^{4}$ Departamento de Ciencias del Mar, Universidad Arturo Prat, Casilla 121, Iquique, Chile
}

\begin{abstract}
Resumen.- Los estudios de variaciones de abundancia de las poblaciones a distintas escalas temporales permiten comprender cómo dichas poblaciones fluctúan en el tiempo y cuáles son los factores que influyen sobre dichas variaciones. Se analizaron los patrones de abundancia del lobo marino común (SASL, Otaria flavescens) a escalas diaria, mensual y anual en 2 loberas reproductivas del norte de Chile. Adicionalmente, se evaluó el efecto de El Niño sobre los patrones anuales de la especie. La abundancia de lobos marinos en Punta Negra (PN) disminuyó desde 1994 a 2011, mientras que en Punta Patache (PP) aumentó, aunque el número de crías fue proporcionalmente bajo. Los resultados demuestran un efecto importante de El Niño sobre la abundancia de lobos marinos, especialmente para hembras + juveniles en PN. La abundancia mensual de hembras y juveniles fue mayor en invierno, mientras que para machos adultos y subadultos no se encontró ningún patrón. Finalmente, durante el día la abundancia incrementa hasta llegar a un máximo hacia fines de la tarde, especialmente en el caso de hembras y juveniles. No se encontraron diferencias en los patrones de abundancia entre las épocas reproductiva y no reproductiva para ninguna de las clases de sexo/edad. Este estudio muestra que la abundancia en PP y PN muestra periodicidades anuales, mensuales y diarias, y que dichas periodicidades están condicionadas tanto por factores intrínsecos (e.g., época reproductiva) como extrínsecos (e.g., hora del día, El Niño). A escala anual, los resultados indican que aún a una escala local, las tendencias de abundancia en 2 colonias pueden ser diferentes.
\end{abstract}

Palabras clave: Circaritmos, actividad en tierra, Otaria byronia

\begin{abstract}
Studies on population abundance variations at different temporal scales contribute to the understanding on how these populations change over time and what are the factors influencing those variations. We analyzed daily, monthly and annual haul-out abundance patterns of South American sea lions (SASL, Otaria flavescens) in 2 breeding colonies of the north of Chile. Additionally we analyzed the effect of El Niño events on the sea lions' annual patterns. The abundance of sea lions in Punta Negra (PN) decreased from 1994 to 2011, whereas in Punta Patache (PP) increased, although the number of pups was proportionately low. Our results indicated a strong effect of El Niño over the abundance of sea lions, especially for females + juveniles in PN. The haul-out monthly abundance of females and juveniles increased during austral winter months, whereas adult and subadult males did not show a clear pattern. Finally, the haul-out abundance tended to increase throughout the day reaching a maximum by late afternoon, especially for females and juveniles. No difference in daily patterns between breeding and non-breeding seasons for any of the sex/age classes was found. This study shows that the number of animals in the PP and PN breeding colonies presented annual, monthly and daily periodicities, and that these periodicities are conditioned by both intrinsic (e.g., breeding period) and extrinsic (e.g., time of day, El Niño) factors. On an annual basis, our results indicate that even at a local scale, SASL population trends at 2 colonies may be different.
\end{abstract}

Key words: Circarhythms, Haul-out activity, Southern sea Iion, Otaria byronia 


\section{INTRODUCTION}

Monitoring programs examining spatial and/or temporal variability in the abundance of a population are critical for both basic and applied ecological studies. Traditionally these programs have been used for management of populations or species, but during the last decades they have gained additional importance as a tool to evaluate natural and anthropogenic influences over fluctuations in population abundance, thus providing a better understanding of the factors causing those fluctuations (Frost et al. 1999, Jemison et al. 2006). In this context, short-, medium-, and long-term estimations of population abundance contribute to the understanding on how they change over time and what are the factors influencing those variations (Jemison et al. 2006).

Otariids (sea lions and fur seals) spend part of their lives in terrestrial habitats on land or ice to raise young, mate, molt, and rest (Riedman 1990, Reder et al. 2003). However, the time these animals spend on land is highly variable, because it depends upon several factors affecting strongly their daily, seasonal and even annual terrestrial abundance and haul-out behavior such as prey availability, predator avoidance, thermoregulation, breeding activity, and environmental effects (e.g., tides, weather, and time of day) (Reder et al. 2003). Depending on the temporal scale, these factors have more or less relevance in the haul-out abundance of sea lions.

The South American sea lion Otaria flavescens (SASL, Shaw, 1800) lives across a broad latitudinal range along the Chilean coast with a population size estimated in about 165,000 sea lions (Venegas et al. 2002, Bartheld et al. 2008, Sepúlveda et al. 2011, Oliva et al. 2012). After a significant reduction of the sea lions population during the sealing period in the middle of the twentieth century (Sielfeld 1999), last surveys performed in Chile suggested that the population is now recovering, at least in northern and southern Chile (Bartheld et al. 2008, Oliva et al. 2012). This population recovery is mainly associated to cessation of hunting, but also is due to the intrinsic capacity of most otariids for rapid population growth and expansion (Bradshaw et al. 2000, Gerber \& Hilborn 2001), and due to current protective legislation, the establishment of nature reserves, and increases in food resources (Lalas \& Bradshaw 2003). In addition, oceanographic fluctuations, changes in ocean productivity, as well as fishery activities may affect the abundance in the long-term (Bradshaw et al. 2000, Read et al. 2006). In this context, low frequency environmental perturbations like El Niño events could modify the quality of sea lions habitat causing important effects on their abundance trends (Sielfeld \& Guzmán 2002, Soto et al. 2004, 2006). In particular, the ENSO 1997/ 1998 caused massive pup mortality for SASL in Chilean and Peruvian coasts, thus showing a strong regulatory effect on the SASL population (Sielfeld \& Guzmán 2002, Soto et al. 2004, 2006). The analysis of a population trend by means of annual estimations is therefore useful in understanding the factors involved in the growth of a population and also to understand ecosystem dynamics (Bowen et al. 2003).

Besides long-term abundance trends, SASL exhibits marked seasonal abundance fluctuations, mainly explained by the notable breeding period that occurs in this species, extending from January to March (austral summer) (Acevedo et al. 2003, Sepúlveda et al. 2012). During this period, the abundance of sea lions in the rookeries arises due to the presence of newborn pups, and adult males and females also that remain on land defending their territories, and caring for and suckling their pups, respectively (Sepúlveda et al. 2012). At the end of this period, most males disperse out to feed and rest (Sepúlveda et al. 2001, Acevedo et al. 2003, Muñoz et al. 2011). Females on the other hand remain with their pups in the colony, alternating their time between pup attendances on land and foraging trips to the ocean (Campagna \& LeBoeuf 1988, Muñoz et al. 2011). During the rest of the year (April to December), sea lions of all ages and sex classes can be seen in the rookeries, although the number of sea lions hauled-out vary considerably in different months (Sepúlveda et al. 2009, 2012). Thus, breeding season constitutes a strong component influencing haul-out patterns on this species.

Previous studies have demonstrated a strong diurnal component to SASL haul-out abundance, with few hauledout sea lions in the morning and maximum numbers of hauled-out individuals in the afternoon (Sepúlveda et al. 2001, 2012), mainly due to the effects of time of day and height of tides. In particular, time of day has typically been examined to determine daily trends in haul-out patterns, relating observed patterns to ambient temperature, intensity of solar radiation, and prey availability in the water column (Calkins et al. 1999). Several studies, both in SASL (Sepúlveda et al. 2001, 2012) and in other species of otariids (e.g., Stirling 1968) have documented a maximum peak of abundance on land during the early afternoon. This pattern could be in response to air temperature, with sea lions more likely to haul-out under conditions of high temperature (Carlens et al. 2006, Andrews-Goff et al. 2010). However, variation 
of this pattern according to month of year and to different age/sex classes of the SASL has also been described (Sepúlveda et al. 2012).

In the north of Chile, Region of Tarapacá, a population size of about 22,000 sea lions has been estimated (Bartheld et al. 2008). Two of the most important breeding colonies on this area are Punta Patache and Punta Negra, with approximately 950 and 1250 individuals, respectively (Bartheld et al. 2008). These rookeries are important not only because of their reproductive condition, but also because they are at a very short distance from the coast $(<50 \mathrm{~m})$ and nearby to a sector of high industrial activity. For these colonies we predicted a strong annual, seasonal and diurnal haul-out abundance pattern. In particular, higher SASL abundance is predicted during the breeding period and also during the early afternoon. On the other hand, it is predicted a negative effect of El Niño events over the sea lions abundance. In this context, the objectives of this study were (1) to determine the daily, monthly and annual haul-out abundance patterns of different age/sex classes of SASL in Punta Patache and Punta Negra breeding colonies in northern Chile; (2) to examine trends in population size on these two breeding colonies, and (3) to analyze the potential effect of the El Niño and La Niña events on the abundance of SASL on these colonies during the study period.

\section{MATERIALS AND METHODS}

\section{STUdY AREA}

This study was carried out in 2 breeding colonies of the SASL in northern Chile: Punta Patache (PP; 20 $48^{\circ} \mathrm{S}$; $70^{\circ} 12^{\prime} \mathrm{W}$ ) and Punta Negra (PN; 2050'S; 70¹0'W) (Fig. 1). PP is composed by 3 rocks located at about $50 \mathrm{~m}$ in front of mainland Chile, whereas $\mathrm{PN}$ is a rock at a distant of about $30 \mathrm{~m}$ from the coast.
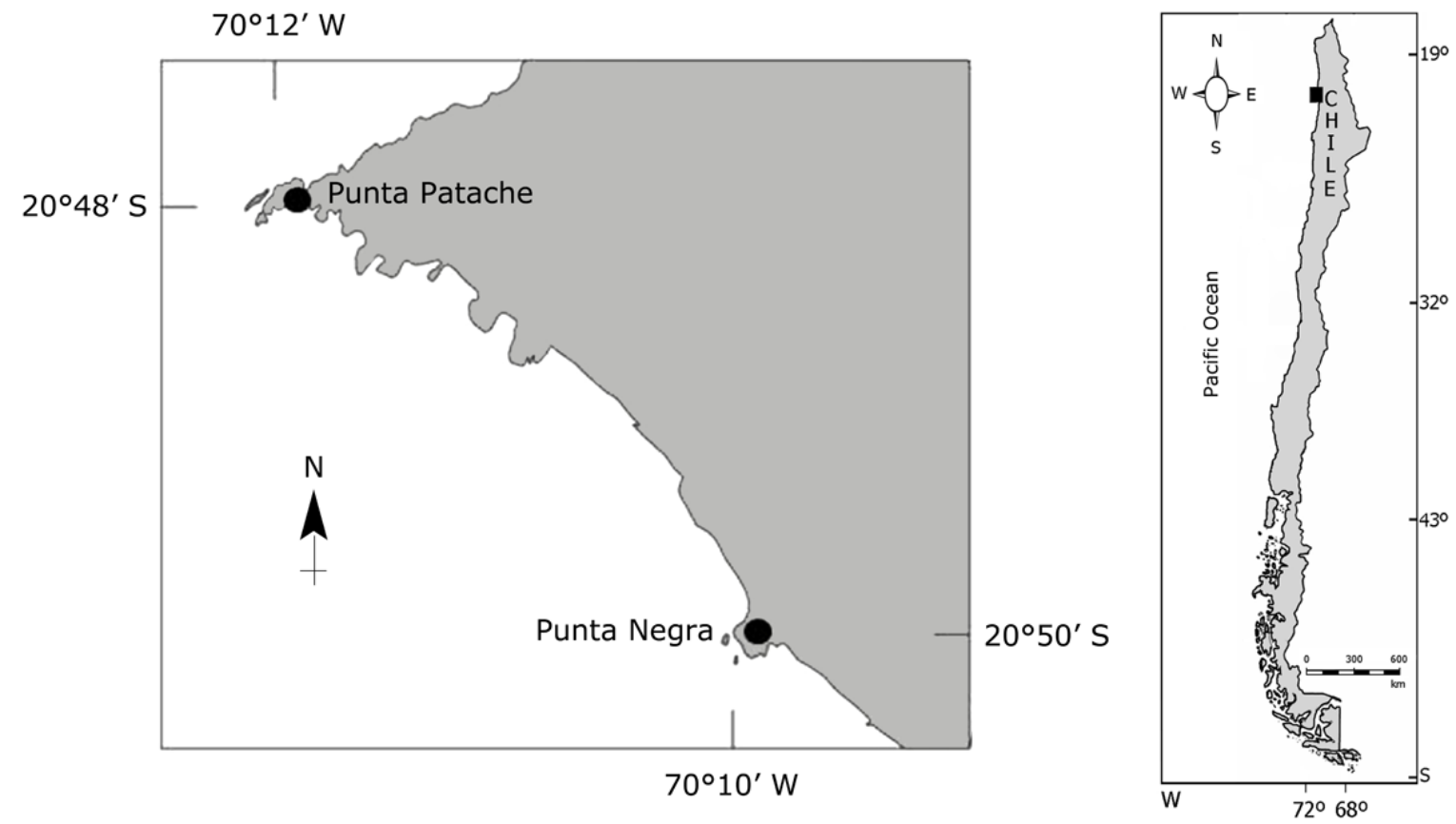

Figure 1. Breeding colony study sites for South American sea lions (Otaria flavescens). Black dots indicate the places where observations were made / Colonias reproductivas del lobo marino común (Otaria flavescens) en el área de estudio. Los puntos negros indican los sitios de observación 


\section{Population surveys of South American Sea lions}

\section{ANNUAL FLUCTUATIONS IN ABUNDANCE}

In both colonies, photographic surveys were made during the breeding seasons of 1994 throughout 2011. Surveys were performed in February, because this month represents the peak of the breeding season for the SASL in the Chilean coast, when most individuals are present at the rookery for reproduction, and almost all pups are already born (Acevedo et al. 2003, Sepúlveda et al. 2009, 2012). For each survey, and during 3 consecutive days, colonies were photographed. Observers were situated in land in front of the colonies, which are both located about 50 to $100 \mathrm{~m}$ off the coast of mainland Chile (Fig. 1). Photographs were taken sequentially and slightly overlapped to guarantee complete coverage of the site. Three independent observers counted the number of sea lions from the photographic records using Photoshop software. Final values were estimated by averaging the counts from the 3 observers, with a maximum error of $10 \%$ among them. Counts falling out from the fixed error were repeated. For each survey, the result with highest abundance of sea lions found in both colonies was considered.

\section{Monthly Fluctuations in ABUndance}

Field work took place at the 2 colonies once a month from October 2010 to September 2011. For each month an aerial survey was performed in a Cessna 150 airplane at an altitude of $120-150 \mathrm{~m}$ with a speed of $100-150 \mathrm{~km} \mathrm{~h}^{-1}$. A set of photographic records was taken with digital cameras CANON 40D and NIKON D300s, zoom lensed 100-400 and 70-200. As mentioned earlier, 3 independent observers counted the number of sea lions from the photographic records, using the same criteria mentioned above.

\section{Daily fluctuations in ABundance}

Punta Patache colony was monitored 3 days/month by two observers from October 2010 to September 2011. The number of sea lions was counted using $10 \times 15$ binoculars and hand tally counters. Counts were conducted at 60min intervals between 08:30 and 18:30. Counts were averaged between the observers, with a maximum error of $10 \%$ among them. Observations points were the same as mentioned above (also see Fig. 1). For each month, sea lion counts were averaged for each time of the day, and then expressed as a proportion of the maximum number of sea lions during the day. Thus, the proportion of sea lions at the time of maximum haul-out abundance was one. This procedure eliminated monthly differences in the number of sea lions in the colony (Lake et al. 1997).

\section{Categorization by age/SeX Classes}

In each of the 3 analyses (annual, monthly and daily) individuals were classified according to age/sex classes as adult males, subadult males, females, juveniles (both sexes), and pups (both sexes). Age and sex were determined from differences in size, body shape and/or coloration (Hamilton 1934, King 1983). Additionally, a category called 'unknown' was included for those animals which due to their position in the colony could not be assigned to any of the previous categories. Pups were considered as a separated age class from January to April, and as juveniles from May to December. This is because from May pups are difficult to distinguish from juveniles $>1$ year, due to similarities in both size and color.

\section{Data analyses}

To evaluate potential annual fluctuations in abundance, the temporal series of abundance for both colonies were compared using the non-parametric Kolmogorov-Smirnov test due to the data was not normally distributed. Analyses were done for each age/sex class separately. Surveys performed from 1994 to 2010 did not discriminate females from juveniles; thus both age/classes were analyzed together. Similarly, no distinctions were made between adult males and subadult males. In addition, to assess the population trend of $O$. flavescens in the study area, the finite population growth rate $(\lambda)$ was calculated for the historic abundance data as: $\lambda=\mathrm{Nt}+1 / \mathrm{Nt}$ (Begon et al. 2006). We only used the rate of change in pup numbers as a measure of the population trend, because pup counts may lead to more accurate estimates (Dans et al. 2004), and because they are also a measure of the productivity of a population (Trites \& Larkin 1996).

A potential relationship between the temporal series of abundance in both colonies during the breeding seasons and El Niño-Southern oscillation (ENSO) events was evaluated. As a quantitative assessment, the multivariate ENSO index (MEI) (Wolter \& Timlin 1993, 1998) was used (NOAA-ESRL) ${ }^{1}$. Monthly data from 1993 to 2010 was considered. To integrate MEI values

${ }^{1}$ NOAA-ESRL. Multivariate ENSO Index (MEI). Earth System Research Laboratory, Physical Sciences Division U.S. Department of Commerce, National Oceanic and Atmospheric Administration <http://www.esrl.noaa.gov/psd/enso/mei/index.html> 
calculated before and during the breeding period of the species, MEI index was averaged from November of a particular year to February on the following consecutive year. MEI index is known to have positive values during the warm phase of ENSO (e.g., El Niño), whereas during the cold phase has negative values (e.g., La Niña). If a negative effect of La Niña or El Niño events is found over the sea lions abundance, then a bell shaped relationship between MEI index and sea lions' abundance is expected, with maximal abundances when MEI values are near zero. To corroborate this, a quadratic model was adjusted to the temporal series of abundance by a Non-linear leastsquare method. A quasi-Newton method was used with 1,000 iterations of the algorithm. This analysis was done separately for males, females + juveniles, and pups from both colonies.

Finally, to visualize possible patterns and/or differences among age/sex classes, and between breeding (January to March) and non-breeding (April to December) seasons, a series of average daily and monthly haul-out distributions analyses were built. In order to test differences in haul-out distribution, a KolmogorovSmirnov test was performed for each age/sex class. To test whether the proportion of sea lions hauled-out varied significantly with time of day and/or among different months, a repeated measures analysis of variance (ANOVA) was used (Underwood 1997) having time of day (11 levels), and month (12 levels) as factors, and the proportion of sea lions as the dependent variable. In order to satisfy assumptions for normality proportion data was logit-transformed $[\log (\mathrm{y} /(1-\mathrm{y}))]$ (Warton \& Hui 2011). If a factor was significant, a Tukey HSD post hoc test was computed to test which factor levels differed. For daily analysis, the data set utilized was the proportion of sea lions hauled-out at each time of day per month (3 observations per month as replicates). All statistical analyses were ran in Statistica 7.0 software (StatSoft Inc. 2004) with alpha $=0.05$.

\section{Results}

\section{Annual variations in abundance}

The temporal series of abundance of males, females + juveniles and pups during the breeding seasons of 1994 to 2011 are shown in Fig. 2. All series showed significant differences in mean abundance (Males: $\mathrm{W}=71.5, P=0.002$; Females + juveniles $\mathrm{W}=85.0, P<0.001$; pups $\mathrm{W}=-111.5$,
$P<0.001)$ over time. The Kolmogorov-Smirnov test indicated significant differences of abundance distribution between the 2 localities for males $(\mathrm{DN}=0.64$, $P<0.01)$, females + juveniles $(\mathrm{DN}=0.67, P=0.003)$, and pups $(\mathrm{DN}=0.94, P<0.001)$.

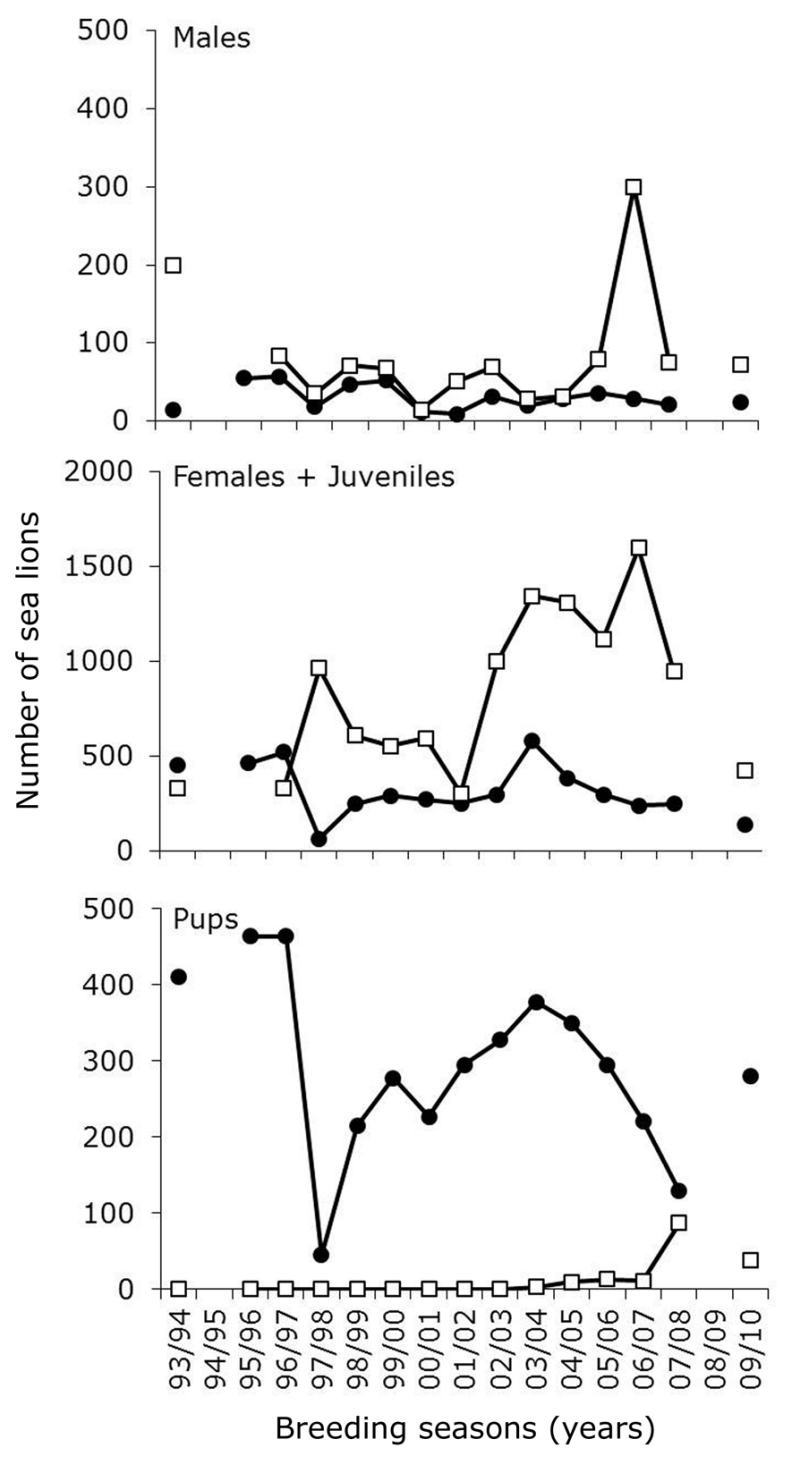

Figure 2. Time series of South American sea lions abundance (number of sea lions per breeding season) for males, females + juveniles, and pups. Punta Negra (PN) is indicated in black circles and Punta Patache (PP) in white squares / Series de tiempo de la abundancia de lobos marinos (número de lobos marinos comunes por época reproductiva) para machos, hembras + juveniles, y crías. Punta Negra (PN) se indica en círculos negros y Punta Patache (PP) en cuadrados blancos 

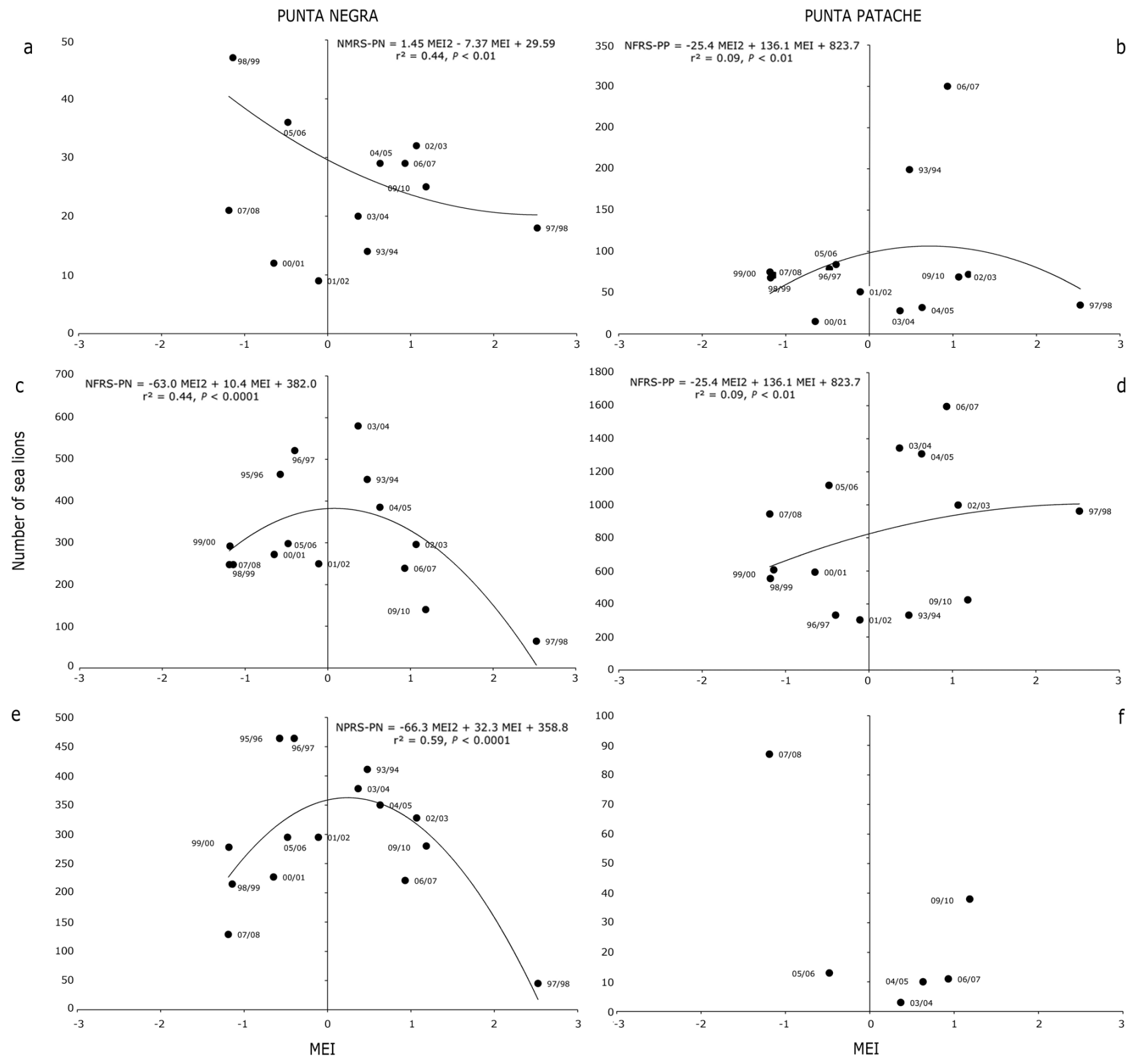

Figure 3. Results of quadratic model fitted to abundance of South American sea lions [number of individuals per breeding season (NSBS) in function of Multivariate ENSO Index (MEI)] in Punta Negra (PN, left column) and Punta Patache (PP, right column). Males (a and b), females + juveniles (c and d), and pups (e and f). The model was not significant for pups from PP (f); females abundance for PP includes both females and juveniles due to difficulties on the field to asses sex visually. Note that all the plots have different scale in the y-axis / Resultados del modelo cuadrático de la abundancia de lobos marinos [número de lobos marinos por época reproductiva (NSBS) en función del índice multivariado de ENSO (MEI)] en Punta Negra (PN, columna izquierda) y Punta Patache (PP, columna derecha). Machos (a y b), hembras + juveniles (c y d), y crías (e y f). El modelo no fue significativo para crías de PP (f); la abundancia de hembras en PP incluye tanto a hembras como juveniles debido a la dificultad de diferenciar ambas clases de edad en terreno. Note que los gráficos tienen escalas diferentes en el eje y 
In PN, from 1994 to 2004, the corresponding finite population growth rates $(\lambda)$ obtained through historic abundance of pups showed a neutral to slightly positive trend (Fig. 2). A notable exception was found in 1998, when a drastic drop in the total abundance (including pups) was registered. The abundance of sea lions exhibited a slight decrease from 2005 to 2008 . Taking into account the number of pups and the total abundance counted in 1994 and compared to 2011, the population of O. flavescens has decreased in this colony. A different situation has been registered in PP. In this locality no pups were registered until 2004, even when the total abundance of sea lions was increasing. From 2004 to 2008 the number of pups showed a positive trend, especially during 2008. Finally, during 2011 when the highest number of sea lions was registered in this colony, the number of pups was proportionately low.

The relationship between the abundance of sea lions and the MEI index showed differences between males and females + juveniles. The abundance of males in both PN and PP did not show a clear pattern with the MEI values (Figs. 3a and 3b). In PP, only in 1993/94 and 2006/ 07 breeding seasons, the abundance was double and triple the mean abundance registered during the rest of the years, respectively. At PN colony, females + juveniles showed a clear relationship with the MEI index (Fig. 3c). On the contrary, they did not show a relationship with this index at PP (Fig. 3d). Similarly, pups showed a clear relationship with the MEI index (Fig. 3e) at PN colony, with lower values of abundance obtained during the 1997/ 98 ENSO. Finally, no relationship was found between pups and the MEI index at PP (Fig. 3f).

\section{MONTHLY VARIATIONS IN ABUNDANCE}

All age/sex classes showed significant differences in abundance among months (Table 1, Figs. 4 and 5). The only exceptions were for males in PN and for pups in PP. In general, males and subadult males did not show a clear pattern of abundance during the year. In PN, the number of males decrease in spring, whereas subadults were absent (Fig. 4). In PP, maximum proportion for males and subadults males were found in June, and from October to January, respectively (Fig. 5). On the other hand, females and juveniles tended to increase their proportion of individuals hauled- out during austral winter (June to September), both in PN and in PP (Figs. 4 and 5).
Table 1. ANOVA results showing hourly and monthly differences in haul out behavior of total, adult males, subadult males, females, juveniles and pups South American sea lions (Otaria flavescens). Hourly analysis corresponds to Punta Patache colony only. Monthly comparisons were performed for Punta Patache (PP) and Punta Negra (PN) colonies. Statistical significant differences are marked in bold / Resultados del ANOVA mostrando las diferencias diarias y mensuales en la abundancia en tierra del total de animales, machos adultos, machos subadultos, hembras, juveniles y crías del lobo marino común (Otaria flavescens). El análisis diario fue realizado únicamente en la colonia de Punta Patache. El análisis de variaciones mensuales fue realizado para Punta Patache (PP) y Punta Negra (PN). Diferencias significativas se indican en negrita

\begin{tabular}{|c|c|c|c|c|c|c|}
\hline & \multicolumn{3}{|c|}{ TOTAL } & \multicolumn{3}{|c|}{ Adult males } \\
\hline & d.f. & $\mathrm{F}$ & $P$ & d.f. & $\mathrm{F}$ & $P$ \\
\hline Hourly (PP) & 10,356 & 25.93 & $<0.0001$ & 10,300 & 1.21 & 0.2870 \\
\hline Month (PP) & 11,356 & 3.81 & $<0.0001$ & 11,300 & 5.01 & $<0.0001$ \\
\hline \multirow[t]{3}{*}{ Month (PN) } & 11,24 & 2.52 & 0.028 & 11,24 & 2.04 & 0.071 \\
\hline & \multicolumn{3}{|c|}{ Subadult males } & \multicolumn{3}{|c|}{ Females } \\
\hline & d.f. & $\mathrm{F}$ & $P$ & d.f. & $\mathrm{F}$ & $P$ \\
\hline Hourly (PP) & 10,268 & 1.71 & 0.0789 & 10,355 & 12.48 & $<0.0001$ \\
\hline Month (PN) & 11,268 & 7.28 & $<0.0001$ & 11,355 & 3.10 & 0.0005 \\
\hline \multirow[t]{3}{*}{ Month (PN) } & 11,24 & 4.06 & 0.002 & 11,24 & 3.87 & 0.003 \\
\hline & \multicolumn{3}{|c|}{ Juveniles } & \multicolumn{3}{|c|}{ Pups } \\
\hline & d.f. & $\mathrm{F}$ & $P$ & d.f. & $\mathrm{F}$ & $P$ \\
\hline Hourly (PP) & 10,357 & 23.47 & $<0.0001$ & 10,104 & 1.32 & 0.2285 \\
\hline Month (PP) & 11,357 & 5.89 & $<0.0001$ & 3,104 & 0.47 & 0.7027 \\
\hline Month $(\mathrm{PN})$ & 11,24 & 4.10 & 0.002 & 11,24 & 5.71 & 0.0002 \\
\hline
\end{tabular}




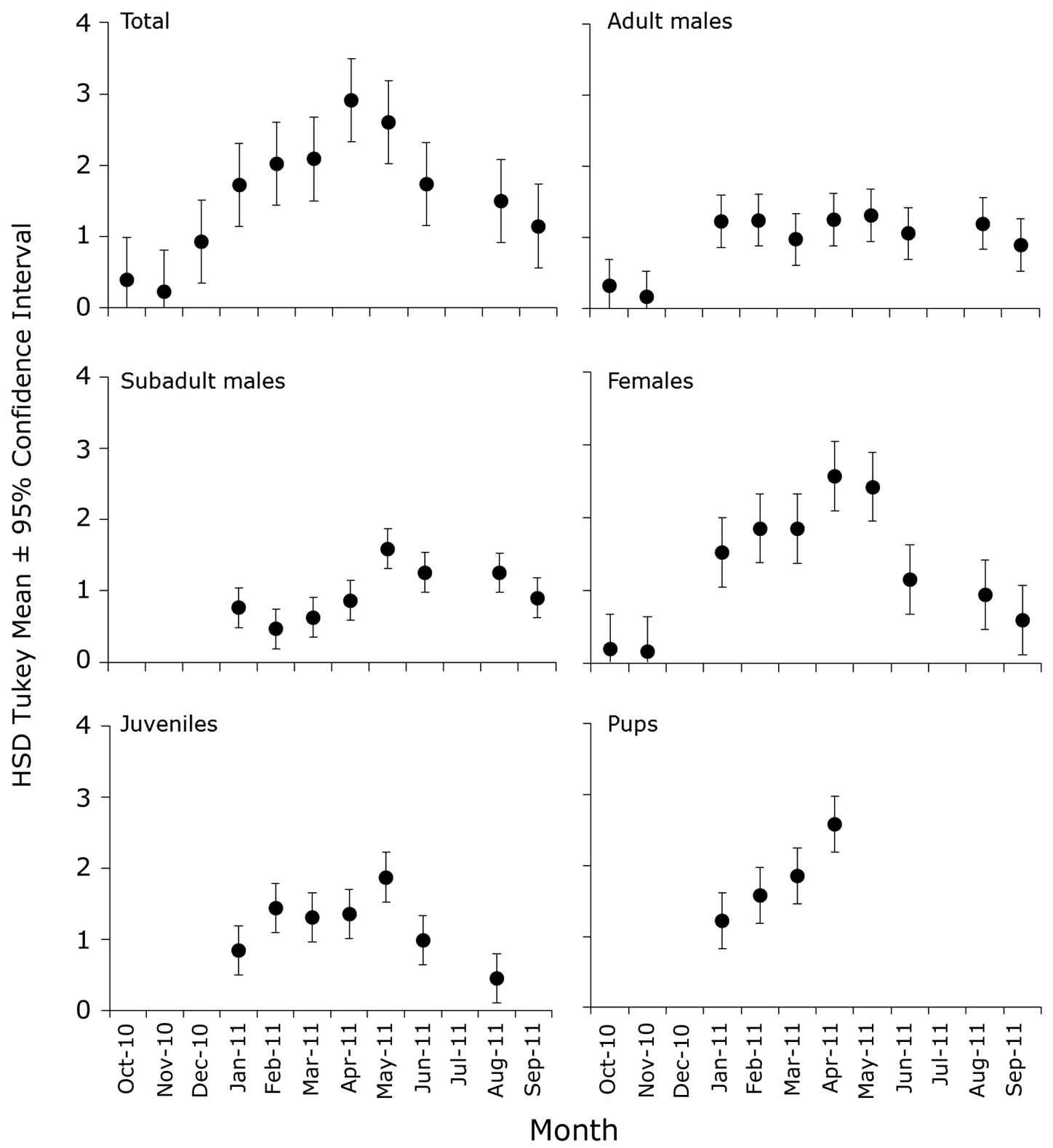

Figure 4. Average monthly proportion (logit transformed) of total South American sea lions hauled-out during the year in Punta Negra breeding colony for the total number of animals, adult males, subadult males, females, juveniles and pups. Bars correspond to HSD Tukey interval of 95\% confidence. Non-overlapping intervals denote significant differences between mean values / Proporción mensual promedio (transformadas) del total de lobos marinos en tierra a lo largo del año en la colonia reproductiva de Punta Negra para el total de animales, machos adultos, machos subadultos, hembras, juveniles y crías. Las barras corresponden al intervalo HSD Tukey con un $95 \%$ de confidencia. Intervalos que no se solapan indican diferencias significativas entre los valores promedio 


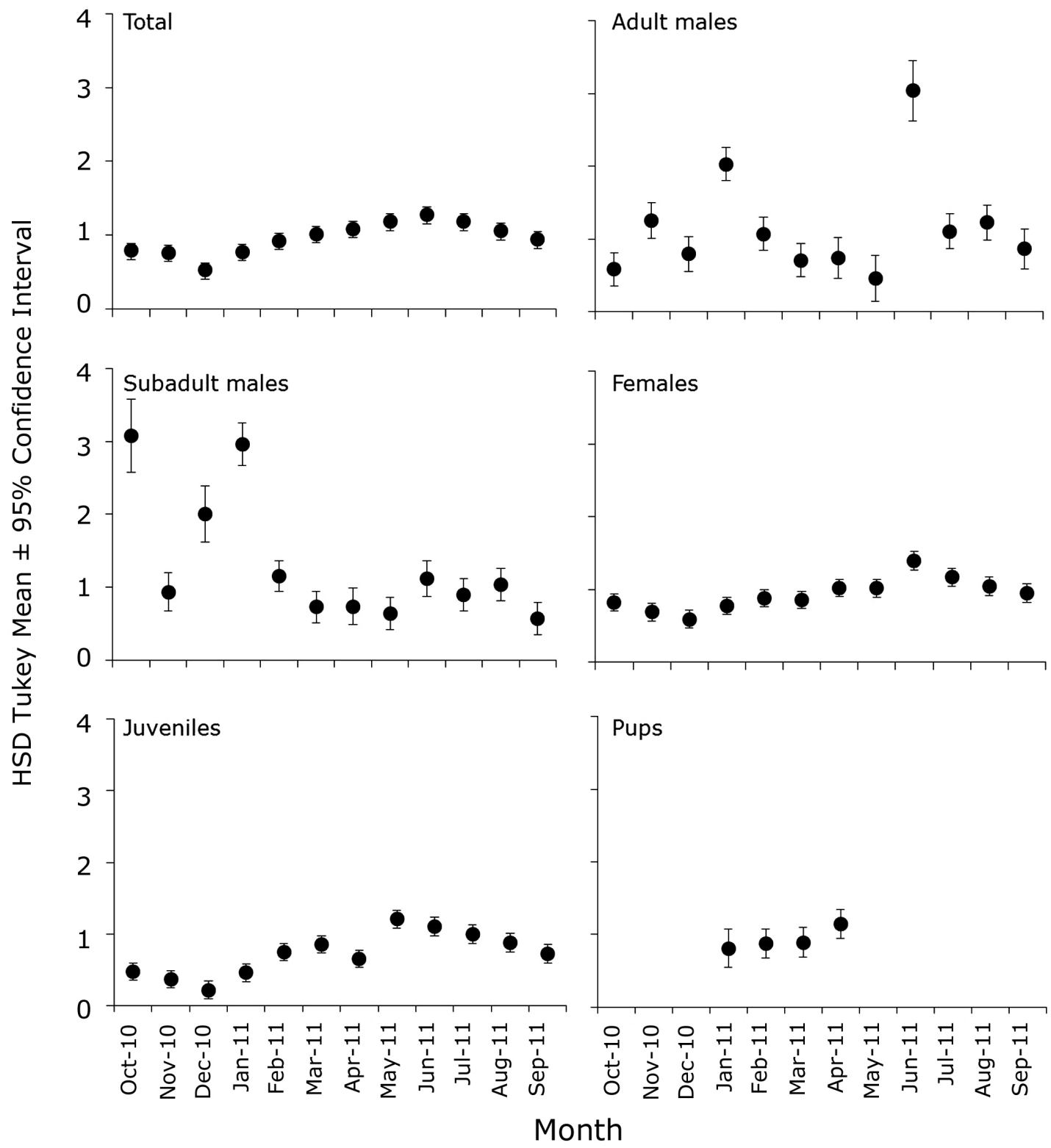

Figure 5. Average monthly proportion (logit transformed) of total South American sea lions hauled-out during the year in Punta Patache breeding colony for the total number of animals, adult males, subadult males, females, juveniles and pups. Bars correspond to HSD Tukey interval of $95 \%$ confidence. Non-overlapping intervals denote significant differences between mean values / Proporción mensual promedio (transformadas) del total de lobos marinos en tierra a lo largo del año en la colonia reproductiva de Punta Patache para el total de animales, machos adultos, machos subadultos, hembras, juveniles y crías. Las barras corresponden al intervalo HSD Tukey con un $95 \%$ de confidencia. Intervalos que no se solapan indican diferencias significativas entre los valores promedio 


\section{DaILY VARIATIONS IN ABUNDANCE}

The daily proportion of total individuals hauled-out tended to increase throughout the day, from about $60 \%$ at 8:00 am to $90 \%$ at $4: 00 \mathrm{pm}$ (Fig. 6). ANOVA results indicated that the total number of sea lions, females and juveniles had significant differences among hours, while males and subadult males did not (Table 1). The highest abundance of females and juveniles was found at the end of the observation period (Fig. 6).

Considering the entire study period, there was no difference between breeding and non-breeding seasons for any of the sex/age classes. Females and juveniles showed a very similar pattern, with no significant differences in hourly proportion of haul-out distribution between breeding and no breeding seasons (Kolgomorov-Smirnov test, $P>0.05$ ). In the case of males and sub adult males (Fig. 7), there is not a clear increasing trend from morning to evening, except for males during the breeding season. Female global haul-out distribution was found to be different to that of males and subadult males, whereas subadult males differed with juveniles (Table 2). Finally, the haul-out distribution of pup showed differences with all other sex/age classes (Table 2).

\section{Discussion}

\section{AnNual Variations in abundance}

Annual variations in the abundance of SASL were recorded at the 2 studied colonies. Historically, PN was the only breeding colony for $O$. flavescens in the area. The abundance of sea lions in this colony increased from 1994 to 1997 , followed by a drastic decrease in 1998 . The increase in the number of sea lions registered in the 1997 breeding season corresponded to the maximum peak of abundance during the study period, before the ENSO 1997/98 event. According to Sielfeld \& Guzmán (2002), the increase in population abundance on this colony during this year, coincided with the finding of some individuals in non-traditional sites around $\mathrm{PN}$, and may be explained by immigration of sea lions from the north, probably in search of food. On the other hand, the decrease registered during 1998 coincided with one of the most severe El Niño events registered in the last century (see below).

\begin{abstract}
Table 2. Kolmogorov-Smirnov test (D) comparing average hourly proportion of haul-out distribution among age/ sex classes of South American sea lions (Otaria flavescens) in Punta Patache breeding colony. Statistical significant differences (P) are marked in bold / Test de Kolmogorov-Smirnov (D) que compara el promedio de la proporción horaria de la abundancia en tierra del lobo marino común (Otaria flavescens) de distintas clases de edad/sexo en la colonia de Punta Patache. Diferencias significativas (P) se indican en negrita
\end{abstract}

\begin{tabular}{ccccccc}
\hline & & Adult males & $\begin{array}{c}\text { Subadult } \\
\text { males }\end{array}$ & Females & Juveniles & Pup \\
\hline \multirow{2}{*}{ Total } & D & 0.9091 & 0.9091 & 0.1818 & 0.6364 & 1.0000 \\
& $P$ & $\mathbf{0 . 0 0 0 2}$ & $\mathbf{0 . 0 0 0 2}$ & 0.9934 & $\mathbf{0 . 0 2 3 3}$ & $<\mathbf{0 . 0 0 0 1}$ \\
Adult males & D & & 0.4545 & 0.9091 & 0.5455 & 1.0000 \\
& $P$ & & 0.2062 & $\mathbf{0 . 0 0 0 2}$ & 0.0758 & $<\mathbf{0 . 0 0 0 1}$ \\
Subadult males & D & & & 0.9091 & 0.8182 & 1.0000 \\
& $P$ & & & $\mathbf{0 . 0 0 0 2}$ & $\mathbf{0 . 0 0 1 3}$ & $<\mathbf{0 . 0 0 0 1}$ \\
Females & D & & & & 0.5455 & 1.0000 \\
& $P$ & & & & 0.0758 & $<\mathbf{0 . 0 0 0 1}$ \\
Juveniles & D & & & & & 1.0000 \\
& $P$ & & & & & $<\mathbf{0 . 0 0 0 1}$ \\
& & & & & &
\end{tabular}




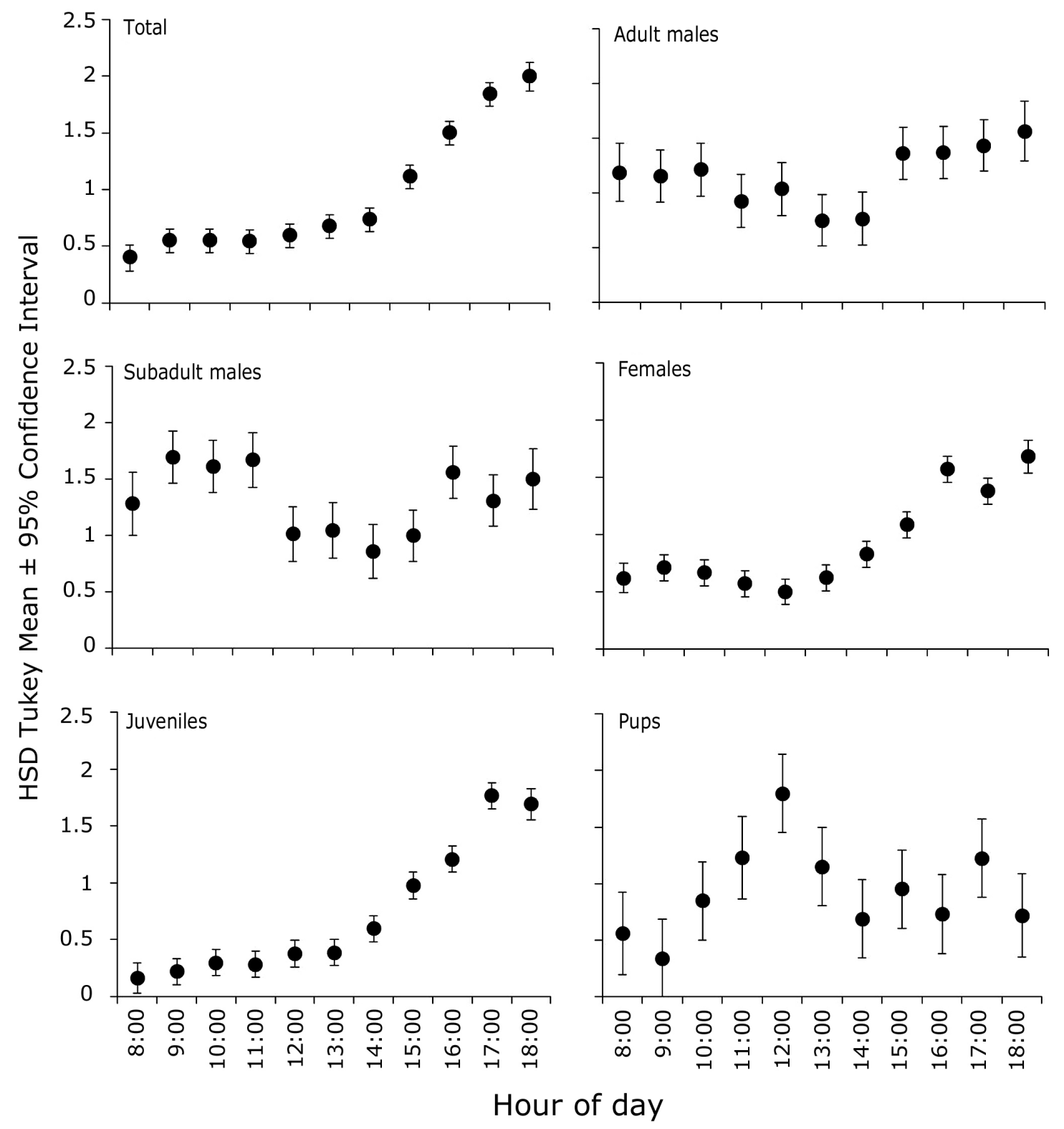

Figure 6. Average daily proportion (logit transformed) of total South American sea lions hauled-out during a year in Punta Patache breeding colony for for the total number of animals, adult males, subadult males, females, juveniles and pups. Bars correspond to the HSD Tukey interval of $\mathbf{9 5 \%}$ confidence. Non-overlapping intervals denote significant differences between mean values / Proporción diaria promedio (transformadas) del total de lobos marinos en tierra a lo largo del año en la colonia reproductiva de Punta Patache para el total de animales, machos adultos, machos subadultos, hembras, juveniles y crías. Las barras corresponden al intervalo HSD Tukey con un $95 \%$ de confidencia. Intervalos que no se solapan indican diferencias significativas entre los valores promedio 


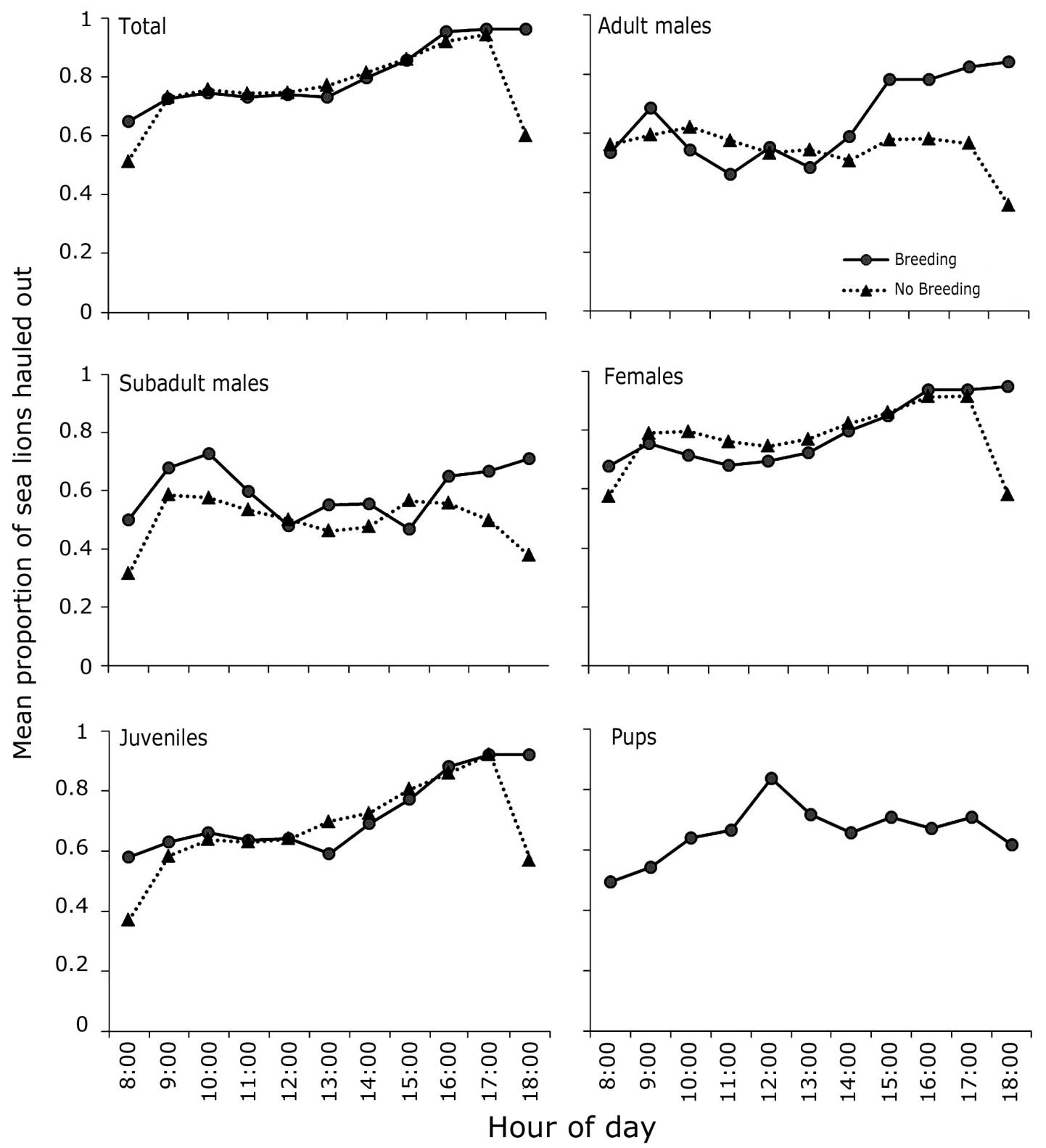

Figure 7. Daily distribution of average proportion (data logit transformed) of hauled- out South American sea lions in Punta Patache for breeding (circles) and non-breeding (triangles) seasons / Distribución diaria de la proporción promedio (transformada) de lobos marinos en tierra en Punta Patache para las épocas reproductiva (círculos) y no reproductiva (triángulos) 
A different scenario was found in PP. In this colony, a positive trend has been registered during the last years. In particular, the presence of pups has been recorded only since 2004. The absence of pups before that year could be explained by overexploitation of this colony during the $20^{\text {th }}$ century, resulting in significant reduction of their stocks (Sielfeld pers. obs.). The increase in animal abundance from 2004 may be due to a recovery after a prolonged period of hunting, as has been reported recently for $O$. flavescens in the coast of Argentina (Dans et al. 2004).

The increase of sea lions abundance in PP coincided with a decrease in PN. These opposite trends suggest an exchange of individuals between both sites. In fact, a recent study made on sea lions from PP equipped with GPS tags demonstrated that sea lions usually visit PN and other colonies in the area (Hevia 2013). Movement of animals between colonies may have a significant influence on the abundance estimations, due for instance to a decrease in the abundance of a colony that may be explained by an increase in another site but not necessarily by an increase and/or decrease in the population growth of the species.

Our results indicated a strong effect of El Niño over the abundance of sea lions, especially in the case of females and juveniles in PN colony. El Niño event causes a decreasing in prey availability, thus increasing the length of foraging trips taken by lactating females, and reducing the frequency of females returning to nurse their pups at land (Arntz \& Fahrbach 1996, Soto et al. 2004, 2006). This could result in massive pup mortality as it has been reported for SASL in Chilean and Peruvian coasts (Limberger 1990, Majluf 1991, Arntz \& Fahrbach 1996, Sielfeld \& Guzmán 2002, Soto et al. 2004), but also for other otariids, such as Galapagos fur seals (Arctocephalus galapagoensis) (Trillmich \& Limberger 1985), Galapagos sea lions (Zalophus wollebaeki) (Trillmich \& Limberger 1985) and California sea lions (Zalophus californianus) (DeLong et al. 1991). In particular, the $1997 / 98$ event was characterized by SASL abortion and premature birth during 1997, mortality of yearlings and adults during 1998 and a strong reduction of birth during the same year (Sielfeld \& Guzmán 2002) and during subsequent breeding seasons (Soto et al. 2004). In PN in particular, after El Niño 1997/98 event, the population of sea lions had never reached historical numbers (Sielfeld \& Guzmán 2002). ENSO events were shown to have a strong regulatory effect on the SASL population in northern Chile. The effect of El Niño on the recruitment rates persists during the present time, whereby the death of pups (females reaching maturity after 3 years), 1 year old young (females reaching maturity after 2 years) and 2 years old young (females reaching maturity after 1 year) resulted in a reduction of the reproductive female population, actually maintaining low pup production (Sielfeld \& Guzmán 2002).

The effects of El Niño seem to be more important in females, and less drastic in males. These results are opposite to what was found by Soto et al. (2004) who indicated that more than $60 \%$ of territorial males died as a consequence of the El Niño in the Peruvian coast. It is possible that in our study area males were not as drastically affected as females as they were in the Peruvian coast due to: (1) males do not need to return to the colony to nurse a pup in a short time, and thus they can leave and forage to other places; (2) males are able to travel more than $300 \mathrm{~km}$ away from the colony, about twice than females (Campagna et al. 2001), thus may have more option to access food; and (3) similarly, they are able to dive more deeply than females and juveniles (Campagna et al. 2001) being potentially less affected by El Niño effects.

\section{MONTHLY VARIATIONS IN ABUNDANCE}

The PP colony showed a marked seasonal variation in abundance and age/sex composition. This variation in abundance was mainly due to variation in the number of females and juveniles, because these categories were the most abundant in the colony. On the contrary, we observed that males and subadult males showed a scattered behavior, being more abundant during spring and summer months. According to these tendencies, and even when PP is currently considered as a breeding colony due to the presence of pups, its seasonal patterns are more according to a non-breeding or haul-out colony. In a non-breeding colony, lowest numbers of sea lions are present in summer since the majority of animals move to breeding colonies during this season, and only subadult males and old males that do not participate in reproduction stay on this kind of colonies (Rosas et al. 1994). On the contrary, the abundance in haul-out colonies usually increases during summer due to sea lions returning to the resting colonies and showing a higher abundance of sea lions from March to December (Sepúlveda et al. 2001).

This unexpected pattern in PP could reflect changes over time in the sea lion colonies due to many influential factors, such as for instance human exploitation (Grandi et al. 2008). It has been described that an increasing sea lion 
population could go through a recolonization process that can be divided into phases (see Roux 1987). The population at PP is probably found in a survival phase extending from the cessation of human exploitation and to the initiation of breeding activities (Roux 1987, Grandi et al. 2008). In this context, although the presence of pups was already reported in this colony, it still does not show the typical monthly and seasonal patterns of the breeding colonies (Acevedo et al. 2003, Pavés et al. 2005, Sepúlveda et al. 2009), and therefore the classification of breeding and non-breeding colonies should be reviewed (Crespo 1988). As established by Grandi et al. (2008) in SASL colonies from the Atlantic coast, the structural and compositional changing process of a colony (from non-breeding to breeding) begins with the establishment of juveniles followed by the incorporation of adult males, subadult males, or both, which yields mixed composition colonies.

\section{Daily VARIaTions IN ABUNDANCE}

A pattern in the daily abundance of females and juveniles SASL in PP colony was observed, with an increase in the abundance of these age classes by late afternoon. Similarly to our results, Rosas et al. (1994) in the Atlantic coast, and Sepúlveda et al. $(2001,2012)$ in central Chile both working with non-breeding colonies, described a similar behavioral pattern in which groups go out from the colony at sunset and come back at sunrise, with greatest number of animals found on land at noon. These studies all suggested a diurnal component in the haul-out behavior of South American sea lions, with most individuals present on land late in the afternoon. A similar pattern has been also documented in other species of pinnipeds, such as Weddell seals Leptonychotes weddellii (Lake et al. 1997), and New Zealand fur seals Arctocephalus forsteri (Stirling 1968).

Sepúlveda et al. (2012) working in a breeding colony from the central coast of Chile found that sea lions (males, females and juveniles) have a peak of haul-out numbers at approximately 1:30-4:30 pm, earlier than the one found in this study. These authors related their patterns to the effects of both air temperature and to feeding habits of their prey, which concentrate mainly on the surface during the night (Fraser et al. 1995). Thus, nocturnal feeding of the South American sea lion may be favored by energy saving due to easier access to prey (Thompson et al. 1998). However, these explanations may not work in the northern coast of Chile because: (1) air temperature is higher than in central-South, and also does not show high variation along the day, and (2) a pelagic foraging of this species has been reported in the study area, with mean dives of $17 \mathrm{~m}$ in depth (Hevia 2013). This author also found that sea lions showed foraging dives during both day and night times, which suggests that SASL in the study area do not need to save energy and thus may feed at different hourly periods. Similar results have been reported in the Atlantic coast, with sea lions diving both at day and night (Riet-Sapriza et al. 2013, Rodríguez et al. 2013). This diurnal and nocturnal foraging behavior of SASL may be also related with the vertical distribution of the anchovy (Engraulis ringens), which is restricted to the first $30 \mathrm{~m}$ (Bertrand et al. 2008), thus being available to marine predators during both day and night.

\section{CONCLUSIONS AND RECOMMENDATIONS}

This study shows that the number of animals in the PP and PN breeding colonies presented annual, monthly and daily periodicities, and that these periodicities are conditioned by different intrinsic (e.g., breeding period) and extrinsic (e.g., time of day, ENSO) factors. On an annual basis, it is important to note that even when the two colonies are very close, no similar trends were found. In this context, our results indicate that even at a local scale, sea lion population trends can be different.

The understanding of the factors causing variation in the status of long-lived and slow reproducing species, such as $O$. flavescens, is especially difficult, since it requires a long-term study. Therefore, long term demographic studies quantifying life history parameters and detecting trends are necessary. Thus, accurate population estimates of the South American sea lion are an essential baseline for developing management and conservation strategies.

\section{ACKNOWLEDGMENTS}

We acknowledge P. Inostroza, J. Barraza, F. Velásquez and G. Pavez for their help in the field, and to Patricia Zárate for language corrections. Financial support for this research was obtained from Compañía Minera Doña Inés de Collahuasi (CMDIC) through the project GMS 2010/ 22.

\section{LITERATURE CITED}

Acevedo J, A Aguayo-Lobo \& W Sielfeld. 2003. Eventos reproductivos del león marino común, Otaria flavescens (Shaw 1800), en el norte de Chile (Pacífico suroriental). Revista de Biología Marina y Oceanografía 38: 69-75. 
Andrews-Goff V, MA Hindell, IC Field, KE Wheatley \& JB Charrassin. 2010. Factors influencing the winter haulout behaviour of Weddell seals: consequences for satellite telemetry. Endangered Species Research 10: 83-92.

Arntz WE \& E Fahrbach. 1996. Experimento climático de la naturaleza, 312 pp. Fondo de Cultura Económica, México.

Bartheld JL, H Pavéz, C Vera, C Manque \& D Miranda. 2008. Cuantificación poblacional de lobos marinos en el litoral de la I a IV Región. Informe Técnico, Fondo de Investigación Pesquera IT/2006-50. <www.fip.cl/ prog_x_year/2006/2006-50.htm>.

Begon M, CR Townsend \& JL Harper. 2006. Ecology: From individuals to ecosystems, $738 \mathrm{pp}$. Blackwell, Oxford.

Bertrand A, F Gerlotto, S Bertrand, M Gutiérrez, L Alza, A Chipollini, E Díaz, P Espinoza, J Ledesma, R Quesquén, S Peraltilla \& F Chavez. 2008. Schooling behaviour and environmental forcing in relation to anchoveta distribution: An analysis across multiple spatial scales. Progress in Oceanography 79: 264-277.

Bowen WD, L McMillan \& R Mohn. 2003. Sustained exponential population growth of grey seals at Sable Island, Nova Scotia. ICES Journal of Marine Science 60: 1265-1274.

Bradshaw CJA, LS Davis, C Lalas \& RG Harcourt. 2000. Geographic and temporal variation in the condition of pups of the New Zealand fur seal (Arctocephalus forsteri): Evidence for density dependence and differences in the marine environment. Journal of Zoology 252: 41-51.

Calkins DG, DC Mallister, KW Pitcher \& GW Pendleton. 1999. Steller sea lion status and trend in Southeast Alaska: 1979-1997. Marine Mammal Science 15: 462-477.

Campagna C \& BJ Le Boeuf. 1988. Reproductive behaviour of southern sea lions. Marine Mammal Science 104: 233-261.

Campagna CRW, W Karesh, MR Marín, F Koontz, R Cook \& C Koontz. 2001. Movements and location at sea of South American sea lions (Otaria flavescens). Journal of Zoology 257: 205-220.

Carlens H, C Lydersen, BA Krafft \& KM Kovacs. 2006. Spring haul-out behavior of ringed seals (Pusa hispida) in Kongsfjorden, Svalbard. Marine Mammal Science 22: 379-393.

Crespo EA. 1988. Dinámica poblacional del lobo marino del sur Otaria flavescens (Shaw, 1800), en el norte del litoral patagónico. Ph.D. dissertation, University of Buenos Aires, Buenos Aires, Argentina, 298 pp.

Dans SL, EA Crespo, SN Pedraza \& MK Alonso. 2004. Recovery of the South American sea lion (Otariaflavescens) population in northern Patagonia. Canadian Journal of Fisheries and Aquatic Science 61: 1681-1690.

DeLong RL, GA Antonelis, CW Oliver, BS Stewart, MC Lowry \& \& PK Yochem. 1991. Effects of the 1982-83 El Niño on several population parameters and diet of California sea lions on the California Channel Islands. In: Trillmich F \& KA Ono (eds). Pinnipeds and El Niño: Responses to environmental stress, pp. 166-172. Springer-Verlag, Berlin.
Fraser NH, J Heggenes, NB Metcalfe \& JE Thorpe. 1995. Low summer temperatures cause juvenile Atlantic salmon to become nocturnal. Canadian Journal of Zoology 73: 446-451.

Frost KJ, LF Lowry \& JM Ver Hoef. 1999. Monitoring the trend of harbor seals in Principe William Sound, Alaska, after the Exxon Valdez oil spill. Marine Mammal Science 152: 494-506.

Gerber LH \& R Hilborn. 2001. Catastrophic events and recovery from low densities in populations of otariids: Implications for risk of extinction. Mammal Review 31: 131-150.

Grandi MF, SL Dans \& EA Crespo. 2008. Social composition and spatial distribution of colonies in an expanding population of South American sea lions. Journal of Mammalogy 89: 1218-1228.

Hamilton J. 1934. The southern sea lion Otaria byronia (de Blainville). Discovery Reports 8: 269-318.

Hevia K. 2013. Seguimiento y análisis de las áreas de alimentación del lobo marino común Otaria flavescens a través de la teledetección. Tesis de Ingeniería Ambiental, Universidad de Valparaíso, Valparaíso, 110 pp.

Jemison LA, GW Pendleton, CA Wilson \& RJ Small. 2006. Long-term trends in harbor seal numbers at Tugidak Island and Nanvak Bay, Alaska. Marine Mammal Science 22: 339-360.

King JE. 1983. Seals of the world, 240 pp. Cambridge University Press, Cambridge.

Lake SE, HR Burton \& MA Hindell. 1997. Influence of time of day and month on Weddell seal haul-out patterns at the Vestfold Hills, Antarctica. Polar Biology 18: 319-324.

Lalas C \& CJA Bradshaw. 2003. Expectations for population growth at new breeding locations for the vulnerable New Zealand sea lion (Phocarctos hookeri) using a simulation model. Biological Conservation 114: 67-78.

Limberger D. 1990. El Niño's effect on South American pinnipeds. In: Glynn (ed). Global ecological consequences of the 1982-83 El Niño Southern Oscillation. Elsevier Oceanographic Series 52: 417-432. Elsevier, Amsterdam.

Majluf P. 1991. El Niño effects on pinnipeds in Peru. In: Trillmich F \& KA Ono (eds). El Niño: responses to environmental stress, pp. 55-65. Springer-Verlag, Berlin.

Muñoz L, G Pavez, P Inostroza \& M Sepúlveda. 2011. Foraging trips of female South American sea lions (Otaria flavescens) from Isla Chañaral, Chile. Latin American Journal of Aquatic Mammals 9: 140-144.

Oliva D, LR Durán, M Sepúlveda, W Sielfeld, R Moraga, G Pavez \& L Muñoz. 2012. Cuantificación poblacional de lobos marinos en las Regiones X y XI y propuesta de escenarios de manejo. Informe Final Proyecto FAP ID 4728 46-LP, 135 pp.

Pavés HJ, RP Schlatter \& CI Espinoza. 2005. Patrones reproductivos del lobo marino común, Otaria flavescens (Shaw 1800), en el centro-sur de Chile. Revista Chilena de Historia Natural 78: 687-700. 
Read AJ, P Drinker \& S Northridge. 2006. Bycatch of marine mammals in U.S. and global fisheries. Conservation Biology 20: 163-169.

Reder S, C Lydersen, W Arnold \& KM Kovacs. 2003. Haulout behaviour of High Arctic harbour seals (Phoca vitulina vitulina) in Svalbard, Norway. Polar Biology 27: 6-16.

Riedman M. 1990. The pinnipeds: seals, sea lions, and walruses, 439 pp. University of California Press, Berkeley.

Riet-Sapriza FG, DP Costa, V Franco-Trecu, Y Marín, J Chocca, B González, G Beathyate, BL Chilvers \& L Hückstädt. 2013. Foraging behavior of lactating South American sea lions (Otaria flavescens) and spatial-temporal resource overlap with the Uruguayan fisheries. Deep-Sea Research II 88-89: 106-119.

Rodríguez DH, M Dassis, A Ponce de León, C Barreiro, M Farenga, RO Bastida \& RW Davis. 2013. Foraging strategies of Southern sea lion females in the La Plata River Estuary (Argentina-Uruguay). Deep-Sea Research II 8889: $120-130$.

Rosas FC, MC Pinedo, M Marmontel \& M Haimovici. 1994. Seasonal movements of the South American sea lion (Otaria flavescens, Shaw) off the Rio Grande do Sul coast, Brazil. Mammalia 58: 51-59.

Roux JP. 1987. Recolonization processes in the subantarctic fur seal, Arctocephalus tropicalis, on Amsterdam Island. In: Croxall JP \& RL Gentry (eds). Status, biology, and ecology of fur seals. National Oceanic and Atmospheric Administration Technical Report NMFS 51: 189-194.

Sepúlveda M, D Oliva \& F Palma. 2001. Daily and annual circarhythms activity in the South American sea lion Otaria flavescens (Carnivora: Otariidae) at the central zone of Chile. Revista de Biología Marina y Oceanografía 36: 181187.

Sepúlveda M, P Inostroza, D Oliva, MJ Pérez-Alvarez \& R Moraga. 2009. Seasonal variation in the abundance of South American sea lions Otaria flavescens in Isla Chañaral colony, Reserva Nacional Pingüino de Humboldt, Chile. Revista de Biología Marina y Oceanografía 44(3): 685-689.

Sepúlveda M, D Oliva, A Urra, MJ Pérez, R Moraga, D Schrader, P Inostroza, A Melo, H Díaz \& W Sielfeld. 2011. Distribution and abundance of the South American sea lion Otaria flavescens (Carnivora: Otariidae) along the central coast off Chile. Revista Chilena de Historia Natural 84: 97-106.

Sepúlveda M, R Quiñones, P Carrasco \& MJ Pérez-Álvarez. 2012. Daily and seasonal variation in the haul-out behavior of the South American sea lion. Mammalian Biology 77: 288-292.
Sielfeld W. 1999. Estado del conocimiento sobre conservación y preservación de Otaria flavescens (Shaw, 1800) y Arctocephalus australis (Zimmermann, 1783) en las costas de Chile. Estudios Oceanológicos 18: 81-96.

Sielfeld W \& A Guzmán. 2002. Effect of El Niño 1997/98 on a population of the Southern Sea Lion (Otaria flavescens Shaw) from Punta Patache/Punta Negra (Iquique, Chile). Investigaciones Marinas 30: 157-160.

Soto KH, AW Trites \& M Arias-Schreiber. 2004. The effects of prey availability on pup mortality and the timing of birth of South American sea lions (Otaria flavecens) in Peru. Journal of Zoology 264: 419-428.

Soto KH, AW Trites \& M Arias-Schreiber. 2006. Changes in diet and maternal attendance of South American sea lions indicate changes in the marine environment and prey abundance. Marine Ecology Progress Series 312: 277-290.

Stirling I. 1968. Diurnal movements of the New Zealand fur seal at Kaikoura. New Zealand Journal of Marine and Freshwater Research 2: 375-377.

Thompson D, CD Duck, BJ Mc Conell \& J Garret. 1998. Foraging behavior and diet of lactating female southern sea lions (Otaria flavescens) in the Falkland Islands. Journal of Zoology 246: 135-146.

Trillmich F \& D Limberger. 1985. Drastic effects of El Niño on Galapagos pinnipeds. Oecologia 67: 19-22.

Trites AW \& PA Larkin. 1996. Changes in the abundance of Steller sea lions (Eumetopias jubatus) in Alaska from 1956 to 1992: How many were there? Aquatic Mammals 22: 153-166.

Underwood AJ. 1997. Experiments in ecology: their logic design and interpretation using analysis of variance, $504 \mathrm{pp}$. Cambridge University Press, Cambridge.

Venegas C, J Gibbons, A Aguayo, W Sielfeld, J Acevedo, N Amado \& C Valenzuela. 2002. Distribución y abundancia de lobos marinos (Pinnipedia: Otariidae) en la Región de Magallanes. Anales del Instituto de la Patagonia, Serie Ciencias Naturales 30: 67-82.

Warton DI \& FKC Hui. 2011. The arcsine is asinine: the analysis of proportions in ecology. Ecology 92: 3-10.

Wolter K \& MS Timlin. 1993. Monitoring ENSO in COADS with a seasonally adjusted principal component index. Proceedings of the 17th Climate Diagnostics Workshop, Norman, OK, NOAA/NMC/CAC, NSSL, Oklahoma Climate Survey, CIMMS and the School of Meteorology, University of Oklahoma, pp. 52-57.

Wolter K \& MS Timlin. 1998. Measuring the strength of ENSO events - how does 1997/98 rank? Weather 53: 315324.

Received 13 November 2014 and accepted 28 January 2015

Associated Editor: María José Pérez Álvarez 